The Geneva Papers on Risk and Insurance, 23 (No. 86, January 1998) 68-80

\title{
Size and Concentration Patterns of the World's Largest Reinsurance Companies
}

\author{
by J. François d'Outreville *
}

\begin{abstract}
By examining the distribution of the total net premiums written by the 100 largest reinsurance companies in the world, this paper documents two dimensions of the change in market concentration: the trend in concentration in the world's largest companies, and the relative position of these companies by countries. A statistical analysis is developed and factors that may have an impact on concentration patterns are examined.
\end{abstract}

\section{Introduction}

The relative decline in economic power of the United States has been well-documented by the popular press. Industries once dominated by American such as the electronic equipment, the automobile industry, and the financial services industry have been subjected to severe pressures from foreign competitors. A comparable shift appears to be occuring in the reinsurance industry which is a significant component of the current account balance of some of the OECD countries (Walter, 1988).

In 1980, eight of the twenty largest reinsurance companies in the world were German reinsurers, seven were American reinsurers and only one was a Japanese company. In 1994, eight were German, six were Japanese, but only five were American companies. Thirty companies from only eight countries share about 70 percent of the world reinsurance market. At the same time, the world market share of the top ten companies also has increased from about 40 percent in 1980 to approximately 45 percent today.

Traditionally, there were only very few international reinsurance markets. London was the most important one because of its unique organization "Lloyds". Germany and Switzerland developed their own reinsurance markets, which still play an important role in the world markets. For many years the United States depended on foreign reinsurance, however, the growth of the US reinsurance companies and the development of markets

* The author is Economic Officer with the United Nations Office at Geneva.

A first draft of the paper was presented at the International Insurance Society Meeting in July 1996 in Amsterdam. Comments from the referees are acknowledged. The opinions expressed in this paper are those of the author and do not necessarily reflect the views of the Organization. 
similar to that of Lloyds have been major trends affecting the increase of reinsurance capacity in the United States. More recently, the rapid expansion of Japanese reinsurance companies has changed the leadership in some reinsurance activities at the expense of reinsurers from the United States and some European countries.

The standard and Poor's Insurance Rating services in their survey continues to believe the 1990s will see a consolidation of the reinsurance industry. Larger players will be increasingly controlling a bigger share of the market. Furthermore, liberalization of trade in financial services inevitably will have an impact on the number of mergers, acquisitions, share swapping, and working arrangements around the world. Changes in the structure of the international market started in 1994 with the acquisition of some major players by US companies. More recently, two US companies took a majority interest in german reinsurance companies. The two moves have placed the US companies closer to the German reinsurance industry.

This paper has two objectives. The first is the documentation of the relative size and market share of the largest reinsurance companies in the world. The second objective is to identify the factors which may explain changes in the positions in the large reinsurance companies in the two major reinsurance markets, i.e. the United States and Germany.

In the next section the data used for the 100 largest reinsurance companies in the world is described. In section 3 the world's largest reinsurance companies by country are presented and in the following section an empirical analysis of the growth of the majore reinsurance markets is developed and the result are presented.

\section{The $\mathbf{1 0 0}$ largest reinsurance companies in the world}

The sizes and quantities of risks normally vary from one company to another and also from one country to another. Previous empirical researches by Mayers and Smith (1990) and Outreville (1995) document that factors such as ownership structure, firm size, market size, geographic concentration and line-of-business concentration influence the demand for reinsurance.

Obtaining comparable data for all reinsurers in all countries is nearly an impossible task. The review ReActions has worked with the International Insurance Solvency and Standard and Poor's to collect data on the world's largest reinsurance companies since $1986 .{ }^{1}$ Data published for the top 100 reinsurance companies from 1987 to 1995 has been used to calculate the percent of total net premiums written of the 100 largest reinsurance companies for every year.

Theoretically, it would be preferable to have the total net premiums written in the world market to calculate market shares. Because it is a nearly impossible task, market shares are based on a denominator consisting of the total net premiums written by the 100

\footnotetext{
1 The listings concentrate on reinsurance premiums and corporate statistics. The premium sections relate to reinsurance operations only and the criterion for inclusion in the list is the level of propertycasualty business written. Information on consolidated groups is also provided but to insure consistency in the data from 1987 to 1995 . Information provided for each company within a group has been used. It is hypothesized that reporting errors for some companies are constant over time.
} 
largest companies. In a compilation of this magnitude problems always arise. Data are difficult or impossible to obtain from companies in certain countries. It is said that the figures from Japan are debatable. Mergers also affect relative rankings from one year to the other. Despite these limitations, it remains the most accurate presentation of the relative position of the largest reinsurers in the world and can be used to construct measures of the relative positions of countries as reinsurance centers.

This section presents the results of static and dynamic measures of concentration, all based on the market shares $q i$ of each company derived from the proportion of net premiums written.

\subsection{Static measures}

The first static measure is the well-known Herfindahl-Hirschman index calculated for the top 100 companies:

$$
H=\Sigma[q i]^{2}
$$

The advantage of this measurement is that it makes it possible to calculate a "number equivalent" of companies $\left(N^{*}=1 / H\right)$ where $N^{*}$ is the potential number of companies of the same size which could exist on the market for a given degree of concentration. ${ }^{2}$

The second measure is Kwoka's (1977) Dominance index:

$$
D=\Sigma[q i-q i+1]^{2}
$$

This emphasizes the gap between successive firms when they are ranked by size. The values of this measure range from 1 to 0 , with the former value indicating a monopolistic market. Conversely, the closer to zero the measure is, the lower is the power of any single company.

\subsection{Dynamic measures}

The other measures reflect changes (dynamic approach). These measures have been calculated for the top 30 companies for the sub-periods 1987-1990, 1990-1993 and 1993-1995. The period has been divided in egal sub-periods (except for the last period) for the needs of the dynamic analysis.

Hymer and Pashigian (1962) developed an index of market share instability:

$$
I=\Sigma|q i-q i, t-n|
$$

If a company was not in the top 30 at either $t$ or $t-n$, its market share for that year is set to zero. The higher the value of $I$, the greater the degree of change in market shares over the period, and by implication, the greater the competitive turbulence and the amount of entry and exit.

${ }^{2}$ An alternative measure to quantify the degree of concentration would be the use of Theil's level of entropy. 
Grossack (1965) has suggested, for determining whether a change in concentration is statistically significant or not, to regress the market shares qi,t on qi,t-n. If the slope coefficient is greater than 1, then concentration as measured by the Herfindahl-Hirschman index has increased. Similarly, if it is less than 1, concentration has decreased.

Tables 1 and 2 present the results of the calculations of the static and dynamic measures respectively. Casual observation reveals some interesting trends. From 1987 to 1994 the market share of the three largest companies slightly fluctuated but at the same time the market share of the ten and fifteen largest companies slightly increased until 1994.

Table 1:

Measures of concentration of the world reinsurance market

\begin{tabular}{lccccccccc}
\hline & 1987 & 1988 & 1989 & 1990 & 1991 & 1992 & 1993 & 1994 & 1995 \\
$\begin{array}{l}\text { Percentage share } \\
\text { of the first: }\end{array}$ & & & & & & & & & \\
$\quad 3$ companies & 25.11 & 24.97 & 24.76 & 24.46 & 24.68 & 23.90 & 25.61 & 29.22 & 24.55 \\
$\quad 5$ companies & 30.75 & 30.72 & 31.66 & 31.89 & 31.73 & 31.11 & 32.23 & 35.51 & 31.05 \\
10 companies & 43.09 & 43.79 & 45.09 & 45.77 & 46.02 & 45.19 & 45.31 & 48.09 & 43.67 \\
15 companies & 52.68 & 53.71 & 55.30 & 54.52 & 56.20 & 55.33 & 54.29 & 55.23 & 51.47 \\
$\quad 30$ companies & 70.65 & 70.59 & 72.26 & 70.51 & 72.33 & 71.21 & 69.70 & 69.91 & 66.82 \\
Herfindahl Index & .0374 & .0377 & .0386 & .0376 & .0383 & .0353 & .0378 & .0483 & .0372 \\
Number equivalent & 26.7 & 26.5 & 25.8 & 26.6 & 26.1 & 28.3 & 26.4 & 20.7 & 26.9 \\
Dominance index & .0083 & .0085 & .0088 & .0090 & .0069 & .0048 & .0057 & .0120 & .0088 \\
\hline
\end{tabular}

Overall, the number of potential competitors derived from the Herfindhal index only slightly fluctuated but the dominance index for the same period decreased. Market share instability has increased from 1987-1990 to 1990-1993. On the other hand, the measure of the change in concentration shows that concentration significantly decreased from 1987 to 1990 and remained unchanged from 1990 to 1995.

Table 2:

Dynamic measures of concentration

\begin{tabular}{|c|c|c|c|}
\hline & $1987-1990$ & $1990-1993$ & 1993-1995 \\
\hline Market share instability & 0.2144 & 0.3374 & 0.2780 \\
\hline Change in concentration: Coefficient & 0.71 & 0.97 & 0.98 \\
\hline Standard error & 0.11 & 0.04 & 0.18 \\
\hline
\end{tabular}


Compared to the same measures calculated for the world's 100 largest banks in 1979 by Tschoegl (1982), the values of the Herfindhal index, Dominance index and market share instability are quite high.

The measure of concentration for consolidated groups is shown in table 3 for the years 1993 and 1995 for which consolidated data are available for the largest 20 groups. Between 1993 and 1995 there was an important change among top reinsurance groups. Although Munich $\mathrm{Re}$ and Swiss Re remain the largest reinsurance groups by a wide margin, both General Re and Employers Re virtually doubled the net premiums they write as a result of the consolidation of their respective German acquisitions.

It is shown in table 3 that the concentration pattern among groups increased significantly between 1993 and 1995 and that the dominance index decreased for the same period.

Table 3:

Measures of concentration for consolidated groups

1993

Percentage share

of the first:

3 groups

37.58

46.65

63.39

10 groups

20 groups

Dominance index:

82.49

.0090

Market share instability between 1993 and 1995

Change in concentration between 1993 and 1995
1995

38.49

52.59

69.04

83.43

.0041

0.2843

$0.97(0.08)$

\section{The world largest reinsurance companies by country}

The percent of the total net premiums written by the 100 largest reinsurance companies in each country for every year from 1987 to 1995 was calculated. The number of reinsurance companies included in the top 100 list was counted by country. In table 4 we present the data for all countries for the selected years, 1987 and 1995.

The market share of the first eight major reinsurance markets totalled $95.18 \%$ in 1987 and $91.61 \%$ in 1995 . The largest companies in the top 30 are domiciled in eight countries. While the market share in the United States has been decreasing over the period, the market share in Germany, Japan and Switzerland has been increasing. Bermuda has also emerged as a major reinsurance center. It is also important to note that the market shares of the scandinavian countries have decreased significantly over the period. The major company in the Netherlands has ceased its writing business and companies from Finland and Norway have disappeared from the list.

With the exception of Bermuda, Brazil and the Republic of Korea, developing countries have certainly not improved their positions in the world reinsurance market. 
Table 4:

Market share and number of reinsurance companies by countries

\begin{tabular}{|c|c|c|c|c|}
\hline \multirow[b]{2}{*}{ COUNTRY } & \multicolumn{2}{|c|}{1987} & \multirow{2}{*}{$\begin{array}{l}1995 \\
\text { Market } \\
\text { share }\end{array}$} & \multirow[b]{2}{*}{$\begin{array}{c}\text { Number } \\
\text { of cies }\end{array}$} \\
\hline & $\begin{array}{c}\text { Market } \\
\text { share }\end{array}$ & $\begin{array}{c}\text { Number } \\
\text { of cies }\end{array}$ & & \\
\hline Germany & 29.20 & 15 & 32.87 & 15 \\
\hline United States of America & 26.85 & 29 & 22.95 & 27 \\
\hline Japan & 12.74 & 16 & 8.15 & 13 \\
\hline Switzerland & 7.73 & 4 & 11.19 & 8 \\
\hline France & 6.72 & 10 & 7.08 & 9 \\
\hline United Kingdom & 5.17 & 7 & 4.08 & 7 \\
\hline Sweden & 3.46 & 3 & 1.00 & 2 \\
\hline Italy & 3.31 & 2 & 4.24 & 2 \\
\hline Finland & 1.00 & 4 & - & - \\
\hline Netherlands & 0.95 & 1 & - & - \\
\hline Norway & 0.64 & 1 & - & - \\
\hline Denmark & 0.50 & 2 & 0.72 & 1 \\
\hline Bermuda & 0.48 & 2 & 2.80 & 6 \\
\hline Bahrain & 0.36 & 1 & 0.33 & 1 \\
\hline Korea, Rep. of & 0.35 & 1 & 0.87 & 1 \\
\hline Brazil & 0.27 & 1 & 0.77 & 1 \\
\hline Iraq & 0.27 & 1 & - & - \\
\hline Australia & - & - & 1.03 & 2 \\
\hline Spain & - & - & 0.30 & 1 \\
\hline Barbados & - & - & 0.42 & 1 \\
\hline Ireland & - & - & 0.55 & 2 \\
\hline \multirow[t]{2}{*}{ Taiwan } & - & - & 0.65 & 1 \\
\hline & 100.00 & 100 & 100.00 & 100 \\
\hline
\end{tabular}

The data from 1986 to 1995 for the six major reinsurance countries are presented in Appendix 1. There are sizable changes in market shares from the beginning to the end of the time period. Figure 1 presents the market shares of these countries.

If the value of a foreign currency increases, obviously the value of the net premium amount written in a country will increase relative to the US market, since all data are converted to a common currency, the US Dollar. The question arises as to whether all the changes noted above are only due to the changes in exchange rate valuation.

For example, the US experienced an increase in market share from 1988 to 1989 when the Dollar was stronger, but this hypothesis cannot explain the increase in 1992. The same relationship can also be observed for Japan in 1989 when the Yen was weaker relative to the US Dollar. 
Figure 1:

Market shares of the six major reinsurance centers

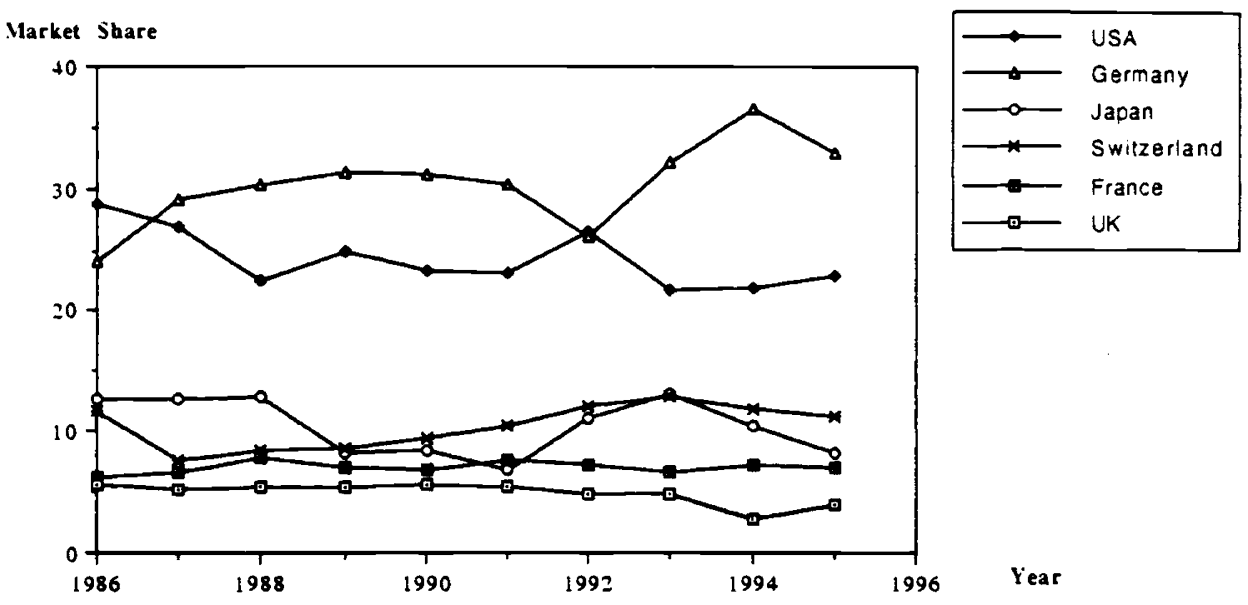

Figure 2:

The relationship between the german market share and the GDP differential between Germany and the United States
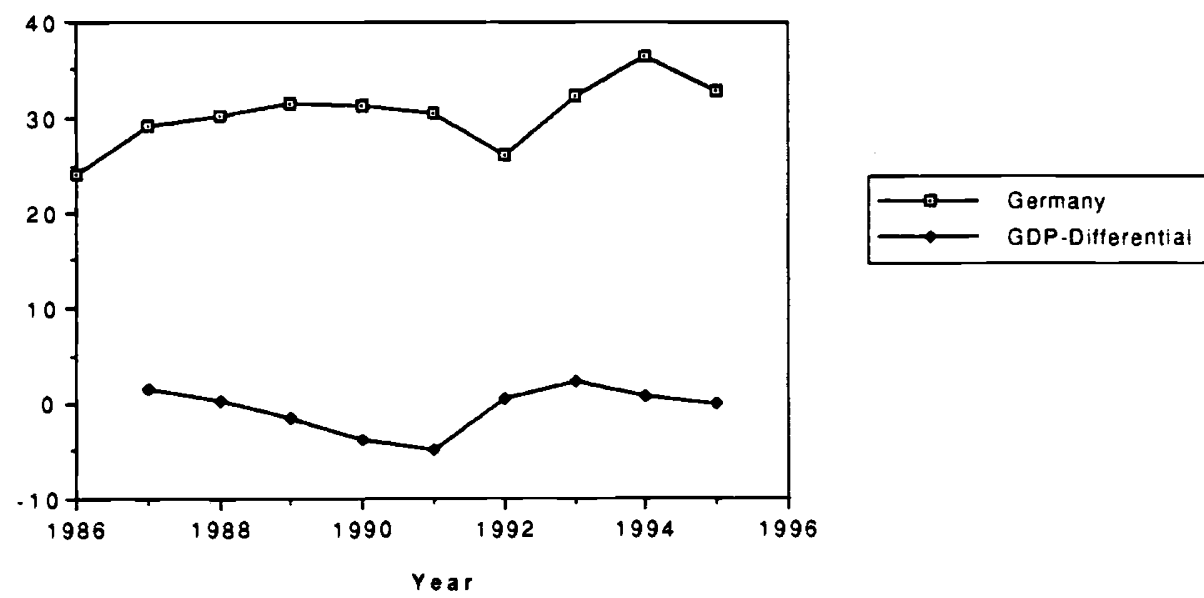
From Figure, 1 it is interesting to notice the inverse relationship between the relative market shares of Germany and the United States which may give some rationale for mergers among companies in these two countries. These two countries also have a large national market base supporting the reinsurance activities of their companies. It is important to verify if economic factors in the two countries, other than currency fluctuations, exhibit a similar pattern.

\subsection{A graphical analysis of economic factors}

Past research in the banking sector suggests that rankings of banks are affected by growth of the domestic economy, levels of international trade and investment, exchange rate fluctuations and differences in government politics (Hart and Pearce (1986), Dohner and Terrel (1988), Goldberg and Hanweck (1991)). At constant exchange rates, interest rates and expected inflation, real growth of the Gross Domestic Product (GDP) should lead to a greater insurance base and, therefore, should be positively correlated with market share.

The impact of these variables was tested for the periods 1986 to 1995 by comparing the macroeconomic variables for Germany and the United States. The difference between the GDP (in real terms), the money market rate and the inflation rate (based on the consumer price index) was calculated for the two countries and plotted against the market share of German reinsurance companies. The results are reported in Figures 2 to 4 and show a similar pattern of fluctuation.

Figure 3:

The relationship between the German market share and the interest rate differential between Germany and the United States

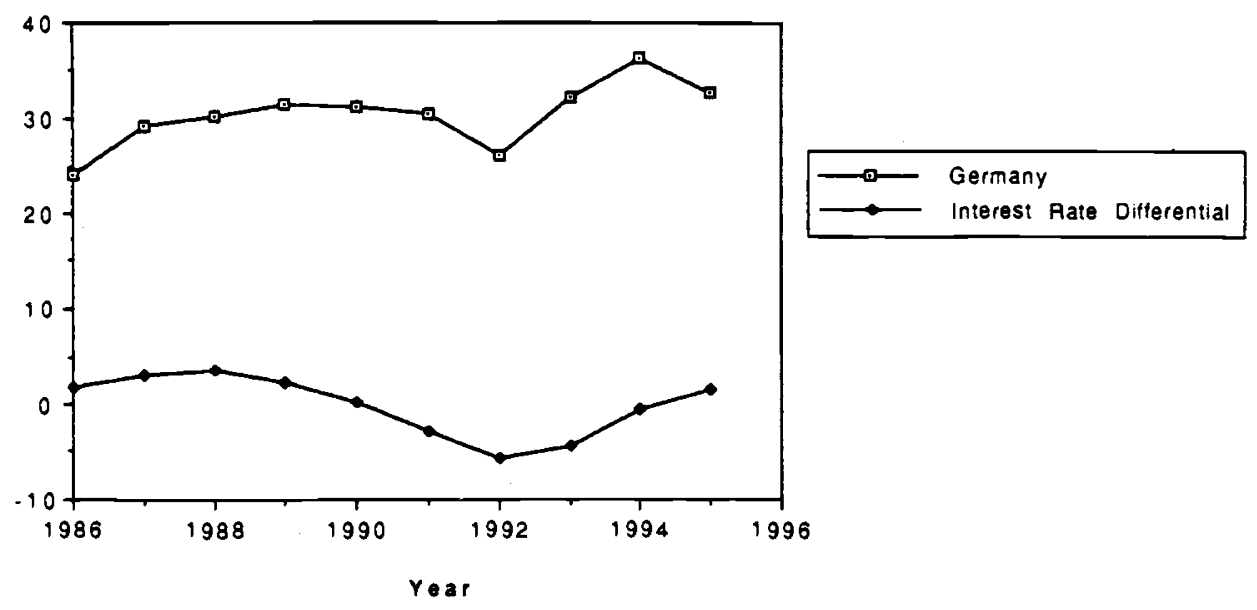


Figure 4:

The relationship between the German market share and the inflation differential between Germany and the United States
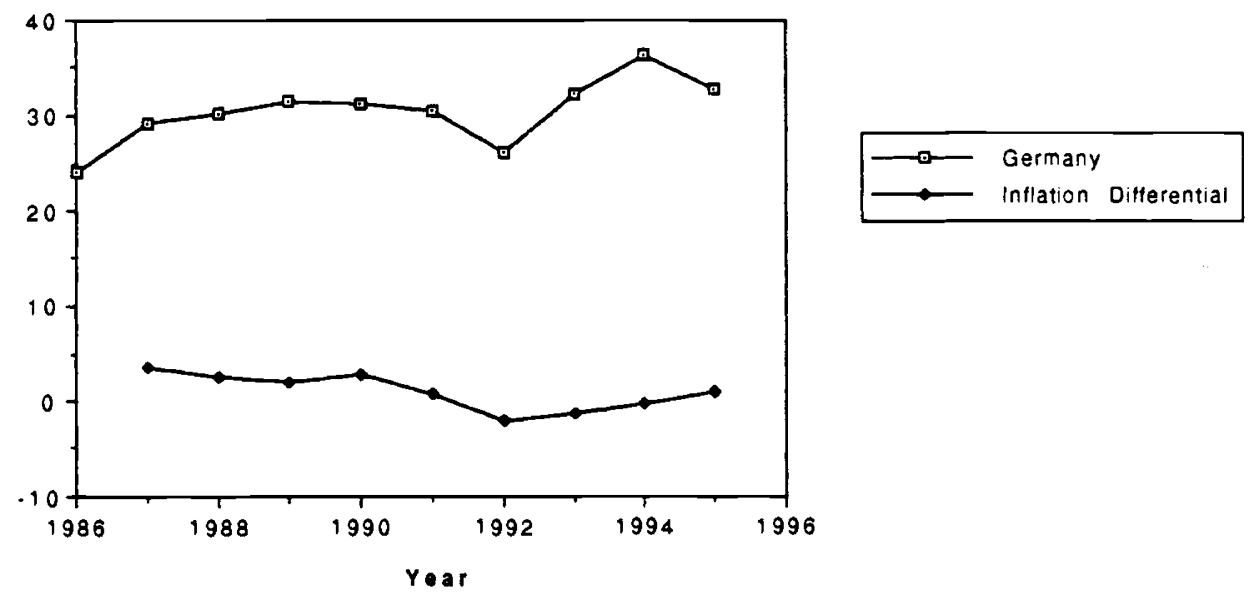

\section{An econometric analysis of the major reinsurance markets}

A number of previous papers have dealt with related questions and serve as methodological bases for the current paper. Some of these papers have examined the growth of the world's largest banks (Goldberg and Hanweck, 1991). Hart and Pearce (1986) have examined the growth patterns of the world's largest firms by using a constant sample of firms from lists published in Fortune magazine.

Using the same model to explain the growth or decline of the market share of reinsurance centers, the author (Outreville, 1996) analyzed the statistical relationship of pooled data for the eight major centers over the sub-periods 1987-1990 and 1990-1993. The results are reported in appendix 2 and the model is represented below: 3

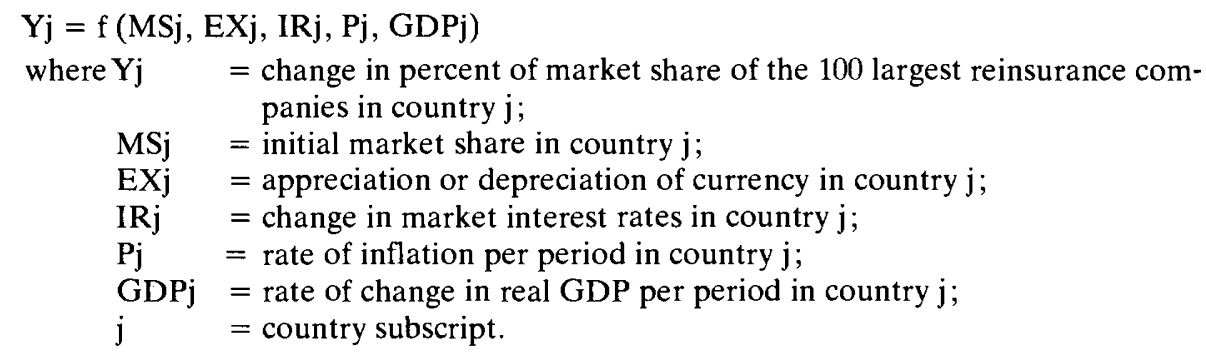

${ }^{3}$ The model is similar to a stock adjustment model and includes the market share of the country at the previous period. It is hypothesized that the adjustment of the market share is due to exogeneous economic factors. 
Changes in a national currency as compared to the average value of Special Drawing Rights (SDR) are used for the eight countries of the analysis. ${ }^{4}$ As expected the appreciation of the national currency significantly explains the increase in the country's world market share.

Changes in interest rates positively affect the market shares of the countries. However, this relationship is not statistically significant over the periods considered in the analysis.

A reduction in inflation or actual deflation of domestic prices has the dual effect of raising relative expected real yields on domestic assets and reversing the deficit and future demand for financing that may affect the stability of the national currency in terms of Special Drawing Rights. A negative relationship between inflation and market share schould be expected. However, a country's inflation rate is likely to be positively associated with a growth in the country's assets and insurancxe premiums. The adjustment of exchange rate and relative prices among countries may neutralize the effect of inflation. These adjustments may also take time before having a perceptible effect.

Surprisingly the relationship between GDP growth and market shares is not statistically significant and shows a negative sign contrary to the expectations.

We present in this paper additional information for the period 1987 to 1995 by countries with the same economic factors on a time-series basis. The results of the partial correlations and multiple regression coefficients are listed in table 5.

For the short-term period examined in this paper, none of the hypotheses are confirmed in the regression analysis. A similar result was reported by Dohner andTerrel (1988) for the world's largest banks.

Table 5:

Correlation coefficients over the period 1987-1995

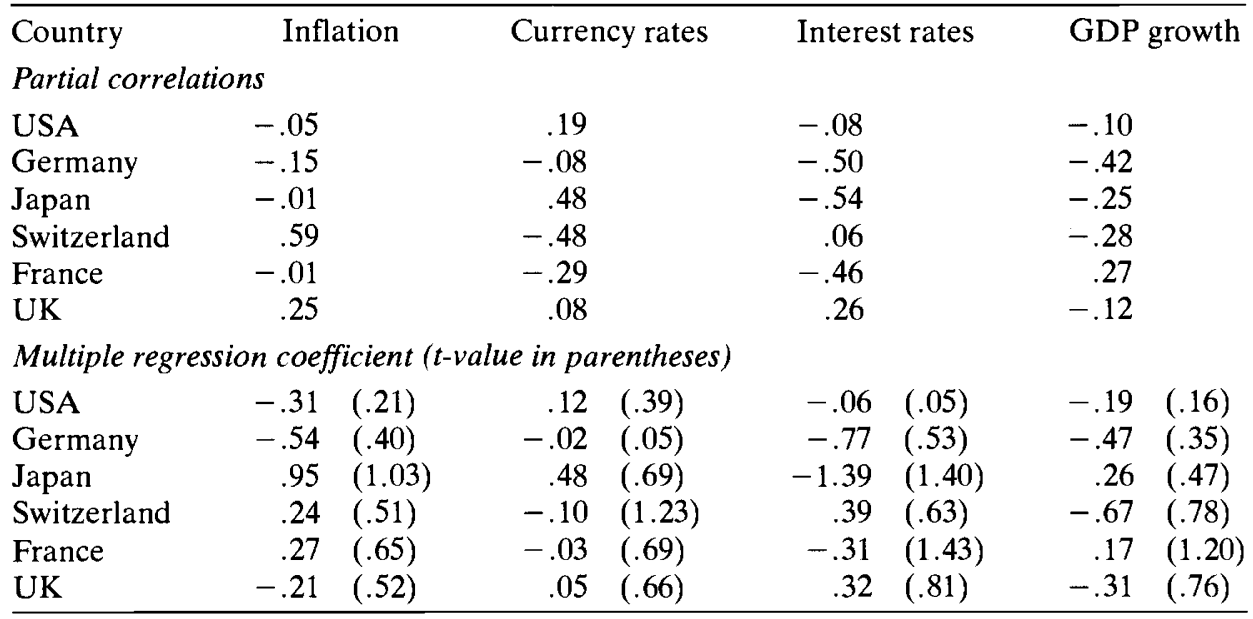

${ }^{4}$ The value of the SDR is determined daily by the IMF on the basis of a basket of currencies with each currency assigned a weight in the determination of that value. The weights broadly reflect the relative importance of these currencies in international trade and finance. 


\section{Conclusion}

There have been a number of changes in the distribution of large reinsurance markets over the period 1987-1995. These changes have caught the attention of professionals and, recently, have attracted some academic interest. By examining the distribution of the reinsurance net premiums of the 100 largest companies in the world, some of these changes have been documented.

Also, there has been an attempt to verify, statistically, which factors may explain these changes. It is clear from the analysis that, on a short-term period, exchange rates are an important factor in determining a country's role as a world reinsurance center. Other countries' domestic factors do not appear to systematically affect the development of world reinsurance centers, at least not on a short-term basis.

Perhaps the lack of confirmation of hypotheses relating to a country's growth is due to increasing internationalization of reinsurance activities. When comparing the economic factors for Germany and the United States, we found some rationale for mergers between companies in these two countries. Perhaps, a similar analysis should be extended, in future research, to other countries to determine the likelihood of mergers.

From the data collected here it is not possible to begin an analysis of the reasons particular countries have developed or not developed as world reinsurance centers. Examination of many of the countries as case studies, would prove to be interesting and useful. The primary objective of this paper is to investigate the major reasons for the changes in positions among countries. 


\section{Appendix 1}

Market share of major countries

\begin{tabular}{lrrrrrrrrrr}
\hline COUNTRY & 1986 & 1987 & 1988 & 1989 & 1990 & 1991 & 1992 & 1993 & 1994 & 1995 \\
USA & 28.81 & 26.85 & 22.61 & 24.84 & 23.40 & 23.10 & 26.45 & 21.64 & 21.98 & 22.95 \\
Germany & 24.16 & 29.20 & 30.30 & 31.43 & 31.20 & 30.42 & 26.06 & 32.20 & 36.51 & 32.87 \\
Japan & 12.68 & 12.74 & 12.92 & 8.26 & 8.54 & 6.90 & 11.12 & 13.08 & 10.52 & 8.15 \\
Switzerland & 11.66 & 7.73 & 8.44 & 8.68 & 9.38 & 10.50 & 12.03 & 12.88 & 11.82 & 11.19 \\
France & 6.33 & 6.72 & 7.76 & 7.01 & 6.77 & 7.60 & 7.22 & 6.66 & 7.30 & 7.08 \\
UK & 5.54 & 5.17 & 5.43 & 5.39 & 5.62 & 5.48 & 4.87 & 4.91 & 2.76 & 4.08 \\
Total & 89.18 & 88.41 & 87.46 & 85.61 & 84.91 & 84.00 & 87.75 & 91.37 & 90.89 & 86.32 \\
\hline
\end{tabular}

\section{Appendix 2}

Estimates of the equation

\begin{tabular}{ccccccc}
\hline Intercept & MS & EX & IR & P & GDP & R2/F \\
\hline $1987-1990$ & & & & & & \\
6.37 & -0.06 & 0.39 & 0.32 & -0.25 & -0.35 & 0.83 \\
& {$[0.73]$} & {$[2.69]$} & {$[0.85]$} & {$[1.03]$} & {$[0.78]$} & 1.93 \\
$1990-1993$ & & & & & & \\
-0.01 & -0.07 & 0.25 & 0.29 & 0.53 & -0.30 & 0.86 \\
& {$[0.73]$} & {$[2.75]$} & {$[0.99]$} & {$[1.19]$} & {$[1.05]$} & 2.43 \\
\hline
\end{tabular}

Note: The $t$ values are shown in parentheses. The equation is estimated with a constant. $R 2$ is the adjusted value of $R^{2}$ and $F$ is the $F$ test.

\section{Appendix 3}

Data sources

Net premiums written

Currency exchange rates,

Market rates, Inflation, GDP
Reactions Standard \& poor's top 100 reinsurers

IMF International Financial Statistics 


\section{BIBLIOGRAPHY}

DOHNER, R. S. and TERRELL, H. S., "The Determinants of the Growth of Multinational Banking Organizations: 1972-1986", Board of Governors of the Federal Reserve System, Washington: International Finance Discussion Paper, No. 326, June 1988.

GOLDBERG, L. G. and HANWECK, G. A., "The Growth of the World's 300 Largest Banking Organizations by Country", Journal of Banking and Finance, vol. 15, 1991, pp. 207-223.

GROSSACK, I. M., "Towards an Integration of Static and Dynamic Measures of Industry Concentration", Review of Economics and Statistics, vol. 47, No. 3, 1965, pp. 301-308.

HART, P. E. and PEARCE, R. D., "Growth Patterns of the World's Largest Firms", Weltwirtschaft. liches Archiv, vol. 122, 1986, pp. 65-79.

HYMER, S. and PASHIGIAN, P., "Turnover of Firms as a Measure of Market Behavior", Review of Economics and Statistics, vol. 44, Feb. 1962, pp. 82-87.

KWOKA, J. E., "Large Firm Dominance and Price-Cost Margins in Manufacturing Industries", Southern Economic Journal, vol. 44, July 1977, pp. 183-189.

KWOKA, J. E., "The Effect of Market Share Distribution on Industry Performance", Review of Economics and Statistics, vol. 61, Feb. 1979,pp. 101-109.

MAYERS, D. and SMITH, C. W., "On the Corporate Demand for Insurance: Evidence from the Reinsurance Market”, Journal of Business, vol. 63, 1990, pp. 19-40.

OUTREVILLE, J. F., "Reinsurance in Developing Countries“, Journal of Reinsurance, vol.2, No. 3, 1995, pp. 42-51.

OUTREVILLE, J. F., "Growth and Concentration Patterns of the World's 100 Largest Reinsurance Companies", Paper presented at the International Insurance Society meetings, Amsterdam, Netherlands, 1996.

RHOADES, S. A., "Concentration of World Banking and the Role of the US Banks among the 100 Largest", Journal of Banking and Finance, vol. 7, 1983, pp. 427-437.

TSCHOEGL, A. E., "Size, Growth and Transnationality among the World's Largest Banks", Journal of Business, vol. 56, No. 2, 1983, pp. 187-201.

TSCHOEGL, A. E., "Concentration among International Banks", Journal of Banking and Finance, vol. 6, 1982, pp. 567-578.

WALTER, I., Global Competition in Financial Services, Cambridge: Ballinger, 1988. 